\title{
Pyridine Nucleotide Transhydrogenase in Normal Human and Leukemic Leukocytes*
}

\author{
Audrey E. Evans † and Nathan O. Kaplan \\ (From the Graduate Department of Biochemistry, Brandeis University, Waltham, Mass., and \\ the Department of Pediatrics, University of Chicago, Chicago, Ill.)
}

The rationale of the study of enzymes in leukemic cells is based on the supposition that malignant change causes an alteration in cell metabolism demonstrable by enzymological techniques. Since more sophisticated methods of cell separation have been reported in the last 20 years (1-4), quantitative analysis of enzymes present in a single cell type can be undertaken. Recent studies of leukemic cells have emphasized enzymes involved in purine and pyrimidine synthesis and the metabolism of folic acid (5-10) in the hope that their activity could be modified as a therapeutic measure. Little work has been carried out on the electron transport reactions of leukemic cells.

The TPNH-DPN or TD transhydrogenase enzyme catalyzes the following reaction: TPNH + DPN TD transhydrogenase lated reaction takes place between the oxidized and reduced forms of DPN. Thus, DPNH $+{ }^{*} \mathrm{DPN}$ DD transhydrogenase

$\rightleftharpoons \mathrm{DPN}+{ }^{*} \mathrm{DPNH}$. Enzymes catalyzing the above reactions have been shown to be present in bacteria, animal tissues, and plants (11-15). In these tissues, TD transhydrogenase is present in the mitochondria and is apparently different from the soluble estrogen-dependent TD enzyme present in the endometrium, mammary, and pituitary glands (16). The function of the two transhydrogenase reactions in vivo is not yet clear, but they may well play an important part

* Submitted for publication January 20, 1966; accepted April 25, 1966.

This work was supported by grants from the American Cancer Society (P77G), the National Science Foundation (GB 1701), and the U. S. Public Health Service (general research support grant FR 5367). It is publication 409 from the Graduate Department of Biochemistry, Brandeis University.

$\dagger$ U. S. Public Health Service Special Fellow. Address requests for reprints to Dr. Audrey E. Evans, Dept. of Pediatrics, Bobs Roberts Memorial Hospital for Children, 920 E. 59th St., Chicago, Ill. 60637. in regulating levels of reduced forms of the two pyridine nucleotide coenzymes.

In 1963, Silber, Huennekens, and Gabrio (17) reported the presence of both TD and DD transhydrogenase in normal and leukemic leukocytes. The leukemic cells exhibited more enzyme activity than the normal controls. These studies were carried out on the supernatant fraction of cell homogenates that had been dialyzed against $0.05 \mathrm{M}$ potassium phosphate buffer.

\section{Methods}

Leukocytes for this study were obtained from 24 normal subjects and 47 patients with leukemia. The pathological specimens were restricted to blood from patients in which the differential leukocyte count was $70 \%$ or more of one cell type. For example, patients with chronic myeloid leukemia had $70 \%$ of cells of the myeloid series, though the maturity varied. More than half (12 of 18) had elevated leukocyte counts $\left(>20,000\right.$ per $\mathrm{mm}^{3}$ ) with metamyelocytes and myelocytes present. Those with normal levels had polymorphonuclear cells and band forms. The patients with acute leukemia were all children and had $70 \%$ or more of blasts. The majority were considered to have lymphoblastic leukemia and six were distinguishable as myeloblastic. Most of the patients were on some form of antileukemic therapy. Twenty $\mathrm{ml}$ of blood was taken from normal subjects and 5 to $20 \mathrm{ml}$ from patients with an elevated leukocyte count; the anticoagulant used was EDTA. An equal volume of $6 \%$ dextran and saline ${ }^{1}$ was added, and the blood was allowed to sediment for 30 to 60 minutes at room temperature. During this sedimentation the supernatant fluid, containing leukocytes and some erythrocytes, was removed and centrifuged in an International refrigerated centrifuge at $200 \times g$ for 7 minutes. The cells that sedimented were washed with $5 \mathrm{ml}$ of $5 \%$ dextrose and water and spun again for 7 minutes at $200 \times g$. The red cells were lysed with $0.2 \%$ hypotonic saline for 30 seconds, and the suspension was corrected to $0.9 \%$ before recentrifugation. Most of the hemoglobin was removed during this step. The final preparation was resuspended in normal saline, and a leukocyte differential count was carried out at this time. Centrifugation at $600 \times g$ for 10 minutes resulted

\footnotetext{
1 Abbott Laboratories, North Chicago, Ill.
} 
in 0.1 to $0.2 \mathrm{ml}$ of packed leukocytes which was stored at $-10^{\circ} \mathrm{C}$.

Before enzyme assay the frozen cells were resuspended in $0.01 \mathrm{M}$ Tris (hydroxymethyl) aminomethane buffer, $\mathrm{pH} 7.5$, and subjected to sonic oscillation for 2 minutes in a Raytheon $10-\mathrm{kc}$ sonic oscillator. The solution was centrifuged in a model $\mathrm{L}$ Beckman Spinco centrifuge at $100,000 \times g$ for 1 hour. The sediment was resuspended in

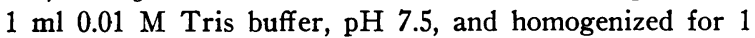
minute in a Teflon hand homogenizer.

The TD transhydrogenase reaction was measured by the use of the acetyl pyridine analogue of DPN (AcPyDPN) according to the following equation (14): $\mathrm{TPNH}+\mathrm{AcPyDPN} \rightarrow \mathrm{TPN}+\mathrm{AcPyDPNH}$. The reaction was measured by following the increase in absorption at $375 \mathrm{~m} \mu$ for 10 minutes. The reaction mixture contained $100 \mu$ moles of phosphate buffer, $\mathrm{pH} 6.5,1$ $\mu$ mole KCN, $0.3 \mu$ mole TPNH, and $0.6 \mu$ mole AcPyDPN in $1 \mathrm{ml}$. The assays were carried out in duplicate at room temperature. Two blanks containing enzyme were run simultaneously; in one of them the AcPyDPN was omitted and in the other, TPNH. Readings were made every minute and standardized against the blank containing TPNH only. The results were corrected by the amount of increased absorption of the blank containing AcPyDPN only. A millimolar extinction coefficient of 5.1 was used to calculate the concentration changes in the reaction. Protein concentration was determined by the method described by Lowry, Rosebrough, Farr, and Randall (18).

\section{Results}

The results were calculated in millimicromoles of $\mathrm{AcPyDPN}$ reduced per hour per milligram of protein in the homogenate. The significance was calculated by the Scheffé test for simultaneous multiple comparisons using $95 \%$ confidence limits (19).

TD transhydrogenase activity was found in both the supernatant fraction and the sediment (Table I). The amount of enzyme in the supernatant fraction was between 55 and 92 m $\mu$ moles per hour per $\mathrm{mg}$ protein and did not vary significantly among the various cell types. Considerable substrate reduction of AcPyDPN took place in the supernatant fraction making a large correction of the figures necessary.

TD transhydrogenase activity was present in the particulate fraction at a five- to tenfold higher level than in the supernatant fraction. In these assays there was practically no endogenous reduction of the AcPyDPN. The normal cells had a TD activity of $241 \mathrm{~m} \mu$ moles AcPyDPN reduced per hour per $\mathrm{mg}$ protein. The result of $366 \mathrm{~m} \mu$ moles ob-
TABLE I

$T D$ transhydrogenase in normal and leukemic leukocytes*

\begin{tabular}{|c|c|c|c|}
\hline \multirow[b]{2}{*}{ Cell type } & \multirow[b]{2}{*}{$\begin{array}{l}\text { No. of } \\
\text { subjects }\end{array}$} & \multicolumn{2}{|c|}{ Transhydrogenase activity } \\
\hline & & $\begin{array}{l}\text { Supernatant } \\
\text { fraction }\end{array}$ & $\begin{array}{l}\text { Particulate } \\
\text { fraction }\end{array}$ \\
\hline & & \multicolumn{2}{|c|}{$m \mu m o l e s / h o u r / m g$ protein } \\
\hline Normal human & 24 & $\begin{array}{l}55 \pm 8 \\
(12-168)\end{array}$ & $\begin{array}{c}241 \pm 16 \dagger \\
(138-390)\end{array}$ \\
\hline Chronic myeloid leukemia & 18 & $\begin{array}{l}55 \pm 10 \\
(0-134)\end{array}$ & $\begin{array}{r}366 \pm 19 \\
(222-558)\end{array}$ \\
\hline $\begin{array}{l}\text { Chronic lymphocytic } \\
\text { leukemia }\end{array}$ & 13 & $\begin{array}{c}68 \pm 12 \\
(14-180)\end{array}$ & $\begin{array}{r}584 \pm 34 \\
(402-756)\end{array}$ \\
\hline Acute myeloid leukemia & 6 & $\begin{array}{l}88 \pm 26 \\
(24-183)\end{array}$ & $\begin{array}{r}558 \pm 76 \\
(492-858)\end{array}$ \\
\hline $\begin{array}{l}\text { Acute lymphocytic } \\
\text { leukemia }\end{array}$ & 10 & $\begin{array}{c}92 \pm 21 \\
(24-261)\end{array}$ & $\begin{array}{l}1,079 \pm 118 \\
(552-1,860)\end{array}$ \\
\hline
\end{tabular}

* TD transhydrogenase $=\mathrm{TPNH}-\mathrm{DPN}$ transhydrogenase. $\dagger 1$ standard error.

tained from the cells of 18 patients with chronic myeloid leukemia was higher than the normal preparations, but the difference was not significant. The $584 \mathrm{~m} \mu$ moles found in cells from patients with chronic lymphocytic leukemia was significantly higher than the activities of normal cells and those in chronic myeloid leukemia. Cells from acute myeloid and acute lymphocytic leukemia had activities of $558 \mathrm{~m} \mu$ moles and 1,079 m $\mu$ moles, respectively. Both were significantly higher than normal. The results of acute myeloid leukemia were not significantly different from chronic myeloid leukemia, but the value from acute lymphocytic leukemia was significantly higher than chronic lymphocytic leukemia.

\section{Discussion}

The results reported by Silber and co-workers (17) showed that there was more enzyme activity in leukemic than in normal cells. However, the amount of TD activity was considerably less than that found in the present study. This is probably accounted for by their method of preparation, which included dialysis against $0.05 \mathrm{M}$ potassium phosphate buffer and discarding of the resultant sediment. In the present study, assay of the DD transhydrogenase was done on a small number of preparations. More DD than TD activity was found in the supernatant fraction, and results were approximately the same as those of Silber and his colleagues for the DD enzyme.

If TD transhydrogenase is a mitochondrial en- 
zyme in human leukocytes as it is in most animal tissues, its presence in the soluble fraction requires explanation. The degree of substrate reduction of the AcPyDPN that occurred in the assays of the supernatant fractions makes it difficult to evaluate the existence of the enzyme in this fraction at all. In the final calculations the degree of nucleotide reduction that resulted from transhydrogenation was frequently less than that derived from the substrate. It is possible that after sonic oscillation a small amount of the enzyme was eluted from the mitochondria and did not sediment at $100,000 \times g$. The TD enzyme was assayed using the pyridine nucleotide analogues thionicotinamide DPN and pyridine-3-aldehyde DPN; the ratio of activity found in the supernatant and particulate fractions was similar to that of the TD enzyme prepared from beef heart mitochondria (13).

Work is now in progress using crude fractionation of leukocyte homogenates centrifuged at 600 and $8,000 \times g$. The specific activity of the TD transhydrogenase increases in the $600-g$ supernatant fraction and is greatest in the 8,000-g precipitate. Electron microscopic examination of this precipitate demonstrated the presence of mitochondria.

In examining the findings obtained from assay of the particulate fraction two facts emerge; more enzyme activity was present in lymphocytes than in myeloid cells, and the greatest activity was present in the immature cells of acute leukemia. The blood used for the normal controls contained a mixture of polymorphonuclear leukocytes and lymphocytes. However, this type of dextran sedimentation allows a larger number of lymphocytes to be lost with the red cells resulting in a final preparation of 70 to $90 \%$ polymorphs. This provides a good control of normal granulocytes for comparison with the cells of myeloid leukemia but is not a completely satisfactory control for abnormal lymphocytes.

The activity of $366 \mathrm{~m} \mu$ moles per hour per $\mathrm{mg}$ protein in chronic myeloid leukemia was higher than the $241 \mathrm{~m} \mu$ moles found in normal cells, but the difference is not significant at the $5 \%$ level. The high normal or increased transhydrogenase activity contrasts with many other enzymes in chronic myeloid leukemia, which are reduced, such as alkaline phosphatase (20). In contrast, four patients with myeloid metaplasia were studied, and the mean was $140 \mathrm{~m} \mu$ moles, which is in the low normal range. In this myeloid disease, the alkaline phosphatase is usually increased in contrast to the relatively low transhydrogenase activity.

Both the chronic and acute lymphocytic forms of leukemia had significantly higher activity in the particulate fraction than the normal controls did. There was a significant difference between 1,079 m $\mu$ moles of enzyme activity in the acute lymphocytic cells and $584 \mathrm{~m} \mu$ moles in the cells of chronic lymphocytic leukemia. The chronic lymphocytic results were significantly higher than the 366 $\mathrm{m} \mu$ moles found in chronic myeloid leukemia. A1though there was not a good control of normal lymphocytes, it would appear that lymphocytes have more transhydrogenase activity than the cells of the myeloid series. The more immature cells had increased TD enzyme activity in contrast to leukocyte alkaline phosphatase, which is absent in myeloblasts and undifferentiated stem cells (21).

Mitochondria are present in both lymphocytes and polymorphonuclear cells but more numerous in lymphocytes $(22,23)$. They are also larger and more numerous in the earlier stages of development (24). Increased numbers and sometimes structural alterations of mitochondria have been noted in leukemic myeloblasts and mouse leukemic lymphocytes $(25,26)$. It is possible that the increase in size and number of mitochondria in lymphocytes and leukemic cells accounts for the varied TD activity found in this study. Another possible explanation is that leukemic cells are more sensitive to sonic oscillation, and the mitochondria are more easily broken, releasing a large number of small fragments. However, Morrow, Bierman, and Jenkins (27) showed that leukemic cells were more resistant to sonic oscillation and required two to four times longer exposure than normal cells to produce similar enzyme activation. In this study, increasing the time of sonic oscillation from 2 to 5 minutes did not increase the amount of available enzyme in the particulate fraction obtained from normal cells.

We made no attempt to evaluate the effect antileukemic therapy had on the leukemic leukocytes, since insufficient specimens were obtained from patients who were not receiving treatment. Sil- 
ber and associates felt that in their results there was no difference between the patients who were and were not on chemotherapy (17).

\section{Summary}

TPNH-DPN (TD) transhydrogenase activity has been assayed in the supernatant and particulate fractions of the leukocytes from 24 normal subjects and 47 patients with leukemia. The results were calculated as millimicromoles of AcPyDPN reduced per hour per milligram of protein. Little TD activity was found in the supernatant fraction, and no difference was noted among the types of cells. The enzyme activity in the sediment of cells from patients with chronic lymphocytic, acute myeloid, and acute lymphocytic leukemia was significantly higher than that in cells from normal controls. The enzyme activity of the cells in acute and chronic lymphocytic leukemia was significantly higher than that in acute and chronic myeloid leukemia.

\section{Acknowledgments}

Computation was done with the assistance of the Biological Sciences Computation Center, University of Chicago, under U. S. Public Health Service grant FR00013 from the Division of Research Facilities and Resources of the National Institutes of Health.

\section{References}

1. Buckley, E. S., Jr., M. J. Powell, and J. G. Gibson II. The separation of the formed elements of whole blood by means of Fraction I. J. Lab. clin. Med. 1950, 36, 29.

2. McKinney, G. R., R. W. Rundles, and S. P. Martin. Respiratory activity of human leukocytes in vitro. Fed. Proc. 1952, 11, 256.

3. Vallee, B. L., W. L. Hughes, Jr., and J. G. Gibson II. A method for the separation of leukocytes from whole blood by floatation on serum albumin. Blood 1947, special issue no. 1,82 .

4. Garvin, J. E. Factors affecting the adhesiveness of human leucocytes and platelets in vitro. J. exp. Med. 1961, 114, 51.

5. Smith, L. H., Jr., F. A. Baker, and M. Sullivan. Pyrimidine metabolism in man. II. Studies of leukemic rells. Blood 1960, 15, 360.

6. Silber, R., B. W. Gabrio, and F. M. Huennekens. Studies on normal and leukemic leukocytes. III. Pyridine nucleotides. J. clin. Invest. 1962, 41, 230.

7. Bertino, J. R., R. Silber, M. Freeman, A. Alenty, M. Albrecht, B. W. Gabrio, and F. M. Huennekens.
Studies on normal and leukemic leukocytes. IV. Tetrahydrofolate-dependent enzyme systems and dihydrofolic reductase. J. clin. Invest. 1963, 42, 1899.

8. Silber, R., B. W. Gabrio, and F. M. Huennekens. Studies on normal and leukemic leukocytes. VI. Thymidylate synthetase and deoxycytidylate deaminase. J. clin. Invest. 1963, 42, 1913.

9. Bresnick, E., and R. J. Karjala. End-product inhibition of thymidine kinase activity in normal and leukemic human leukocytes. Proc. Amer. Ass. Cancer Res. 1964, 5, 26.

10. Roberts, D., and T. C. Hall. Folic reductase activity of human white blood cells. Proc. Amer. Ass. Cancer Res. 1964, 5, 211.

11. Colowick, S. P., N. O. Kaplan, E. F. Neufeld, and M. M. Ciotti. Pyridine nucleotide transhydrogenase. I. Indirect evidence for the reaction and purification of the enzyme. J. biol. Chem. 1952, 195, 95.

12. Kaplan, N. O., S. P. Colowick, and E. F. Neufeld. Pyridine nucleotide transhydrogenase. III. Animal tissue transhydrogenase. J. biol. Chem. 1953, 205, 1.

13. Kaufman, B., and N. O. Kaplan. Pyridine nucleotide transhydrogenase. VIII. Properties of the transhydrogenase reactions of an enzyme complex isolated from beef heart mitochondria. J. biol. Chem. 1961, 236, 2133.

14. Stein, A. M., N. O. Kaplan, and M. M. Ciotti. Pyridine nucleotide transhydrogenase. VII. Determination of the reactions with coenzymes analogues in mammalian tissues. J. biol. Chem. 1959, 234, 979.

15. Keister, D. L., A. San Pietro, and F. E. Stolzenbach. Pyridine nucleotide transhydrogenase from spinach. I. Purification and properties. J. biol. Chem. 1960, 235, 2989.

16. Villee, C. A. The role of steroid hormones in the control of metabolic activity in The Molecular Control of Cellular Activity, J. M. Allen, Ed. New York, McGraw-Hill, 1962, p. 297.

17. Silber, R., F. M. Huennekens, and B. W. Gabrio. Studies on normal and leukemic leukocytes. V. Pyridine nucleotide transhydrogenases. J. clin. Invest. 1963, 42, 1908.

18. Lowry, O. H., N. J. Rosebrough, A. L. Farr, and R. J. Randall. Protein measurement with the Folin phenol reagent. J. biol. Chem. 1951, 193, 265.

19. Brownlee, K. A. Statistical Theory and Methodology in Science and Engineering. New York, John Wiley, 1960, p. 252.

20. Valentine, W. N. The metabolism of the leukemic leukocyte. Amer. J. Med. 1960, 28, 699.

21. Wachstein, M. Alkaline phosphatase activity in normal and abnormal human blood and bone marrow cells. J. Lab. clin. Med., 1946, 31, 1. 
22. Bessis, M. Haemopoietic tissue and blood. Lymphoid tissue in Electron Microscopic Anatomy, S. M. Kurtz, Ed. New York, Academic Press, 1964, p. 149.

23. Schwind, J. L. The supravital method in the study of the cytology of blood and marrow cells. Blood 1950, 5, 597.

24. Pease, D. C. An electron microscopic study of the red bone marrow. Blood 1956, 11, 501.

25. Ackerman, G. A., J. A. Grasso, and R. A. Knouff. Morphological and histochemical studies of the leukemic cells from a patient with atypical myelo- blastic leukemia with special reference to intracytoplasmic mucopolysaccharide vacuoles and fibrillar formation. Blood 1960, 16, 1253.

26. Albert, S., C. O’Mara, and I. Pryjma. Size and mitochondrial content of normal and leukemic mouse lymphocytes. Proc. Amer. Ass. Cancer Res. 1964, 5, 4.

27. Morrow, P. L., H. R. Bierman, and R. Jenkins. Effects of ultrasonic vibration on the formed elements of blood from normal and leukemic subjects. J. nat. Cancer Inst. 1950, 10, 843. 